inguinal ring, as suggested in my paper. These are the cases which offer the greatest difficulty to the operating surgeon. In the intra-peritoneal variety, and also in Mr. Lane's case, a sac is found and an obscure structure discovered behind it; suspicion will naturally arrive with regard to its character, and some surgeons have succeeded in identifying the bladder without opening it. But we meet with a totally different state of things in those cases of which I have brought forward an instance. Here the surgeon cuts down through the different layers with the intention of exposing a supposed bernial sac; at last be reaches what appears to be the sac, but what in reality is the bladder; it is opened and the mistake recognised either at once or, more frequently, some time afterwards. I confess I do not see how in these cases injury to the bladder can be avoided; at all events, the six surgeons who hitherto have been unfortunate enough to meet with such cases were unable to avoid it.

I am, Sirs, yours truly,

West-street, Finsbury-circus, May 14th, 1894. ERNST Michels.

\section{"EMPYEMA IN CHILDHOOD."}

\section{To the Editors of THE LANCET.}

SIRs, - I have read Dr. Sturges' letter with reference to my paper in THE LANCET of May 5 th with much interest. As regards his statement: "In almost all cases, as I now believe, resection is needed," coming from so eminent an authority, it must carry much weight. After carefully going through the old notes and records and observing the practice at the Children's Infirmary, Liverpool, at the same time taking into consideration the grave importance of the subject, and though I may be living in one of Dr. Sturges' "slages of belief," I have come to the conclasions mentioned in my paper. My object in writing was not, however, so much to dogmatise on the treatment as to publish the results during ten years at a large children's hospital, with an analysis of the fatal cases. With reference to the high mortality of nhildren under three years of age I venture to state that, whatever form of treatment is adopted, the death-rate will remain a very high one. Though I have not recently seen any records of duration of illness, I take it that an average duration of 8.8 weeks, taken from seventy-seven cases, is not by any means prolonged. The words "major operation" were used in a comparative and not superlative sense. With regard to the question of treatment of the twenty-nine fatal cases, I hope to have a further short communication to make, but would now point out that in fourteen there was, besides the condition of empyema, either pericarditis or peritonitis to deal with, and in two the children came into hospital too late, with the lung riddled with sinuses, secondary to rupture of an empyema.-I am, Sirs, yours obediently,

Rawdon, Yorks, May 12th, 1894.

J. P. WIGHTMAN.

\section{AN ETHICAL QUESTION.}

\section{To the Editors of THE LANCET.}

SIRs,-In a recent monthly magazine I observed an article on "Modern Surgery" by a London surgeon. Let me pat before you a parallel case. I, your humble correspondent, a suedical man, court public favour by having roy name, my address, and my qualifications (ability) made known in a local newspaper in $\mathrm{my}$ own neighbourhood, and in this simple and direct way only, I advertise myself in my own neighbourhood. Your space $\mathrm{I}$ know is valuable, but I do want you to tell me and your readers in what sense my conduct in thus adrertising can be thought by my confreres unprofessional or dishonourable, when, so far as I can see, the other larger and more glaring way of advertising is held to be irreproachable?

\section{Truro, May 11th, 1894.}

I am, Sirs, yours faithfully, WM. DALE, M. D. Lond.

\section{SCARLET FEVER (?)}

To the Editors of THE LANCET.

SIRs,-It would be interesting to know what those cases proved to be which are mentioned in the report of the zublic health ${ }^{1}$ as having been sent into hospital as scarlet tever, diphtheria, or enteric fever, but after sojourn were differently diagnosed. It is evident that if these cases occurred in considerable numbers, as stated, there must be some prevailing cause, probably epidemic, for symptoms of a kind so like those of scarlet fever as to lead to notification and removal. Having had personal experience during the last few weeks of cases extremely like scarlet fever, but differing in some important respects from that disease, may I ask you to assist in clearing up this question, or at least to consider whether or not the subject deserves fuller inquiry?

May 8th, 1894

I am, Sirs, yours faithfully, R. L.

\section{MANCHESTER.}

\section{(FrOM OUR OWN CORRESPONDENT.)}

The Queen and the Manchester Ship Canal. IT appears definitely settled that Her Majesty the Queen will not make a personal voyage along the Ship Canal.

Whitsuntide School Processions.

It has long been the custom here for the Sunday-school children to walk in procession through the streets on Whit Monday. The Roman Catholic schools have a procession of their own on the Friday. On some other day excursions are made to places more or less distant, sometimes so far away that many hours are spent in the train and the children reach home at night worn out with fatigne. The march through the streets, though at first no doubt enjoyed, becomes a weary drag, more especially to the smaller ones. In rough, wet weather these poor children, often lightly and flimsily clad, suffer considerably, and it is not pleasant to contemplate the permanent injury to many of them as the result of these Whitsuntide festivities. $\Lambda$ lively correspondence has been going on in the papers on the subject, sume writers objecting-and not without fair grounds - to the complete interruption of the ordinary traffic, so that a person may not be able to get from one part of the town to another for an hour or two. Numbers of people lose their trains and their tempers, while the benefit to the schools and the community is very doubtful. Without doing away with the march altogether, its length might be curtailed with advantage to the children and less inconvenience to the public, and school managers will, it is to be hoped, display more wisdom and more thought, so as not to overtax the powers of weakly children not accustomed to long-continued exertion.

\section{The Society of Fellons of the Royal College of Surgeons of England.}

It was resolved at a meeting of the Central Executive Conncil of this society, held in London on April 18th, that the Fellows resident in Manchester and district should be invited to form a branch Executive Council. In accordance with this invitation a meeting of the local Fellows was held on Thursday, when the following resolation, moved by Mr. F. A. Southam and seconded by Mr. A. H. Young, was carried unanimously :- "That a Branch Executive Council in connection with the Society of Fellows of the Royal College of Surgeons of England be formed in Manchester." The following Fellows were then elected :-Mr. James Hardie (chairman), Mr. F. Jones, Mr. H. W. Pomfret (hon. secretary), Mr. C. Richmond, Mr. F. A Southam, Mr. W. Thorburn, Mr. G. A. Wright, and Mr. A. H. Young.

\section{NORTHERN COUNTIES NOTES.}

(FroM OUR OWN CORRESPONDENT.)

\section{A Hospital in Dock.}

The Tyne Port Sanitary Hospital, which has been moored at Jarrow Slake since it was built in 1886, has been docked on the pontoon belonging to Smith's Dock Company, North Shields, for painting and overhauling. This floating hospital was built so that the underwater portion could be taken out, in sections and repaired, as at the time of its construction there was no dock in the conntry wide enough to take in the hospital, which is not less than $80 \mathrm{ft}$. wide. The one-sided pontoon dock at North Shields has, however, got over this difficulty. It only took thirteen minutes to lift the hospital on the dock.

The state of some of the villages in North Yorkshire 